\title{
Villy Sørensens aktualitet
}

\section{En anmeldelse af Jørgen Bonde Jensen: Litterar arkaoologi.}

Studier i Villy Sørensens Formynderfortaellinger. Gyldendal, 1978.

Studenterbevægelsen fra 68 og frem gjorde temmelig kort proces med kultur-radikalismen fra de tidlige 60ere. Det forekommer nu, som om den hårdhændede afskrivning af denne tradition nok så meget skal forstås som gruppepsykologisk end som egentlig politisk eller erkendelsesmæssigt betinget. Afskrivningen foregik ikke mindst $\mathrm{i}$ selvmarkeringens og identitetsopbygningens interesse. Under opbygningen af en socialistisk fagkritik udskilte studenterbevægelsen traditioner, som havde været blandt forudsætningerne for denne fagkritik.

Markeringen af ' 68 ' som det altafgørende skelår fungerer også som en del af denne selvmarkering, og forskellige jubilæumsskriverier - som ellers har været stærkt selvransagende - har desværre kun befæstet nogle af disse myter om det bratte erkendelsesskred i 68 . Hvad der stadig underbetones er, at en række af studenterbevægelsens indsigter var vundet tidligere - omend, unægteligt, ikke for så mange som efter 68: i Studentersamfundet, i anti-atomkampagnen i de tidligere 60ere, i engagementet mod franskmændene i Algier og senere amerikanerne $\mathrm{i}$ Vietnam. $\mathrm{Og}$ det forbigås, at mange kulturradikale gjorde disse bevægelser med og bidrog til at opbygge de indsigter, som en eftertid har post-dateret til ' 68 '.

Men fadermordet - eller set på en anden led: fornægtelsen af egen baggrund - var en realitet fra sidst i 60erne. Det gjorde kun forplumringen større, at kulturradikalerne selv reagerede allergisk, med fortegnende angreb på studenter-og ungdomsoprør; angreb som i øvrigt oftest foregav forståelse og analyse. F.eks. var Villy Sørensen med til (i 'Den oprørte generation' fra 68) at udbrede et billede af ungdommens protest som en - $\mathrm{i}$ sin inspiration grundlæggende apolitisk og antimaterialistisk følsomheds opgør med fadergenerationen. En tolkning, som netop studenternes angreb på ham og hans jævnaldrende efterhånden desværre kun kunne bekræfte ham $i$.

Hvad de socialistiske fagkritikere skrev imod deres forgængere var ikke nødvendigvis forkert, men mangelfuldt. Mihail Larsens 
'Kritik af den kulturradikale pædagogik' og Ebbe Sønderriis' ideologikritiske analyse af Villy Sørensens forfatterskab var eksempler på behandlinger, som havde den erkendelsesledende interesse, at de regressive træk i kulturradikalismen skulle blotlægges. Og diskussionen om den adækvate fortolkning af Kunstfonddebatten i 65 førtes fra materialistisk hold med den samme interesse. Hvad der vitterligt eksisterede af statsloyalitet, kulturfetichisme og ringeagt over for rindalisterne hos de radikalere, der ytrede sig $i \quad 65$, blev gjort til hele sagen.

Det blev slået fast $\mathrm{i}$ en bredere studenteroffentlighed, at kulturradikalismen hverken var konsekvent materialistisk eller revolutionær, og denne insisteren kunne være nyttig, sålænge bevægelsen prøvede at finde sine egne ben. $\mathrm{Nu}$, hvor alt dette er blevet almindelig lærdom - i hvert fald i den fagkritiske del af humaniora - er det imidlertid vigtigt at genoverveje, hvilket progressivt indhold der også kunne ligge i kulturradikalismen. Ikke for at 'yde den retfærdighed' i abstrakt forstand, men såmænd for en materialistisk selvforståelses skyld. Hvad foregik der faktisk i vor nære og delvis egen fortid? Hvilke kritiske traditioner, der ligefrem er blevet en 'anden natur' i progressive bevægelser anno 78, blev opbygget tilbage i 50erne og 60erne?

'Litterær arkæologi' af Jørgen Bonde Jensen er en analyse af Villy Sørensen 'Formynderfortællinger' fra 1964. Analysen suppleres med kortere behandlinger af de tidlige historier fra 50erne. Og endelig indplacerer Bonde Jensen formynderfortællingerne $\mathrm{i}$ en politisk og kulturel efterkrigssammenhæng. Jeg ser bogen som et vigtigt forsøg på en gentilegnelse af de skitserede traditioner. Ud fra den afgrænsede gruppe tekster kommer den langt i retning af at klarlægge kulturradikalismens progressive sider. Den gør det i større sympati med - og i en sikrere materialistisk forståelse af baggrunden for - tekstenes forestillingsverden end f.eks. Sønderriis' bog, som især blev problematisk ved at lægge sigtepunktet ved den sene Vietnam-bevægelse og dermed så at sige kom til at angribe de tidlige fortællinger for deres mangel på bagklogskab.

Jeg mener også, at Bonde Jensen med sin meget konciliante holdning kommer til at fortegne den sørensenske kulturradikalisme på et par vigtige områder. Det skal jeg siden vende tilbage til.

Selve tekstanalyserne, som er bogens hoveddel, er meget indgående og sindrige. De er primært nærlæsninger, der ekspliciterer teksternes egen forestillingsmønstre, og hvis det ikke 
lyder af noget særligt, bør man genopfriske, hvilke nødder der er at knække i disse fortællinger. Specielt indlæsningen af isotopier (Theseus-myten i I det fremmede især), hvor jeg selv og andre tidligere kun har fundet en uoverskuelig mangfoldighed, er givtig. Bonde Jensen udreder teksternes tematik (herunder betydningsbærende stilistiske træk) i overensstemmelse med de indbyggede konceptioner - han forsøger derimod ikke at læse dem 'symptomalt', som han selv f.eks. har 'læst' Carlberg-sagaen i sin foregående bog, men Sørensen-teksternes exceptionelt høje bearbejdningsniveau gør også en symptomallæsning mindre ligetil, og forudsætter en analyse som den her givne. Der er altså endnu noget at gøre, men grundlaget er sandelig lagt.

Da jeg ikke er så sikker på, i hvor høj grad 'man' får uddybet sin indsigt $i$ 'Formynderfortællinger' og deres forfatter, skal jeg nøjes med at tale på egne vegne. Jeg har stort set fået min egen læsning af historierne bekræftet, men under- og udbygget gennem et utal af detailobservationer og syntetiseringer. Og jeg ser tydeligere end før den rationelle plan bag Sørensens historiske udfoldelse af formyndertematikken, hans opfattelse af brud og kontinuiteter i indre og ydre tvangsmekanismer fra oldtiden til fremtiden.

Men samtidig er behovet for en kritisk forholden sig til det fremlagte også vokset. Således har en 'beriget' læsning af En fremtidshistorie gjort mig stadig mindre overbevist om relevansen af dens eskatologiske forestillinger. Skræmmebilledet af et totalt styret og forud-kalkuleret samfundsliv kunne virke nogenlunde plausibelt, hvis sigtet var at fremsk rive autoritære korporativismetendenser, men netop den slags syner er ikke på tale her. Fortællingen minder om dårlig Adorno. Og denne har endda set mere dialektisk på den fremadskridende samfundstvang; det forvaltede samfund må, for at kunne fungere, isprænges zoner af uberegnelighed og overlevethed: 'Hvad der ikke i sig selv kan afledes af dets funktion, har dog en sådan; det bestående samfund formår ikke slet og ret at udfolde sig af sit eget princip, men må forbinde sig med noget førkapitalistisk, arkaisk; virkeliggjorde det sit eget princip uden tilsætninger af noget, der var forskelligt fra det, 'ikke-kapitalistisk', så ville det ophæve sig selv.' ('Einleitung in die Musiksoziologie', s. 51). Sørensens fremtidsskildring er handlingsmæssigt kompleks, men røber den større indsigt i samfundsanliggender end f.eks. Huxleys 'Fagre ny verden'? Det forekommer mig også mere litterært dybsindigt end erkendelsesbefrodrende, at skildringen af det teknologiske fremtidssamfunds upersonlige 
beherskelsesforhold er svøbt i Ødipus-mytens stærkt personaliserede relationer. Specielt hvis fremtidssamfundet befordrer tendenser $i$ retning af psykisk 'faderløshed', og udvikling af nye mentale problemer, således som bl.a. Mitscherlich og Ziehe har beskrevet det.

I øvrigt får netop en 'beriget' (strukturel) læsning - der viser ethvert navn som betydningsbærende, ethvert handlingselement som mytisk eller mod-mytisk indmontering - den effekt, at fortællingernes elementer tårnes op i ret få paradigmesøjler med relativt faste indbyrdes relationer. En vis skematisme bliver påtrængende, når man én gang har fattet den driftsmæssige indebyrd af heste, hunde, tunger, etc. Det er naturligvis en oplevelse, der kan ledsage enhver gennemført strukturel analyse, men jeg tror, den er særlig stærk i dette tilfælde, fordi så mange af billederne og symbolerne kun snævert varierer en traditionel freudiansk topik.

Det bemærker Bonde Jensen selv, men i forbindelse med de tidlige historier, ikke 'Formynderfortællinger'. Han skriver f.eks. om Den gamle ejendom: 'Man kan også spørge om hovedbilledet (skillevæggene) i tilstrækkelig grad udfolder sig efter sine muligheder. Er det ikke undertiden i for høj grad blot billede på noget andet, som foreligger som et bevidsthedsfaktum før billedet? Simpelt overføringsbillede?' (s. 229).

'Et bevidsthedsfaktum før billedet' - formuleringen kræver en kort ekskurs, som stadig har med billedbrugen at gøre. Diskussionen om den billedmæssige rigdom vs. skematik i Villy Sørensens fortællinger har været ført længe, men for mig at se ud fra en forkert position. Diskussionen har nemlig været sammenkoblet med en diskussion om, hvorvidt fortællingerne var resultatet af en ubevidst eller bevidst skabelsesproces.

Underforstået var det en fælles antagelse, at en "ubevidst konception' ville borge for billedmæssig rigdom. Det var imidlertid et problematisk kriterium, ikke blot fordi det forvandlede spørgsmålet om den billedmæssige fylde til et rent genetisk spørgsmål, men også, fordi det byggede på en misforståelse af det ubevidstes og dets ytringers natur som ren og rig spontaneitet. Sagen er, at 'det ubevidste' er en psykisk kategori, der er socialt præget som andre områder i psyken. $\mathrm{Og}$ dets vigtigste medium, drømmen - som den sære digtning gerne sammenlignes med - er ydermere et kompromisprodukt mellem drømmetanker og censurinstanser, isprængt 'dagsrester' fra den umiddelbare 
hverdagssituation.

Det vil sige, at også en 'spontan' billedskaben på flere måder vil være socialt præformeret. $\mathrm{Og} i$ denne konkrete sammenhæng betyder det, at Sorensens billedanvendelse, med dens affinitet til Freud og Jung, hænger nøje sammen med den skrivendes sociale væren, uanset om tekstproduktionen er 'spontan' eller 'kalkuleret' $i$ ordenes traditionelle betydning. Læsning af psykologisk teori og intellektuelt kendskab til freudiansk topik kan - som alle andre sociale erfaringer - komme til udtryk i 'spontan' kreativitet. Og spontan kreativitet kan være snæver til det monomane, hvad f.eks. tvangstanker er vidnesbyrd om.

Jeg tror personligt på det ubevidstes store meddelagtighed i Villy Sørensens fortællinger. Det forhindrer mig blot ikke $\mathrm{i}$ at finde hans billedanvendelse skematisk, for det kan den også være uden kalkulation.

Alt dette kræver en vigtig modifikation, for Bonde Jensen påpeger med rette (s. $182 \mathrm{ff}$.), at billedanvendelsen er afstemt efter den historiske situation i de enkelte fortællinger. Det historiske miljø er $i$ hvert fald til en vis grad bestemmende for, hvilke dele af billedrepertoiret der aktualiseres (visse gengangere er der nu). De enkelte fortællinger lugter af den tid, de foregår i, og i øvrigt er formynder-tematiken langthen begrebet historisk specifikt, hvad Bonde Jensen viser med stor omhu.

Det er vigtigt - bl.a. fordi tidligere ideologikritiske analyser af forfatterskabet har fortalt os noget andet - at Bonde Jensen så eftertrykkeligt dokumenterer, at Sørensen ser historien som en dynamisk proces, med kontinuiteter og nydannelser $\mathrm{i}$ formyndermyndlinge-forholdet forklaret ud fra bredere samfundsændringer. Han slår samtidig fast, at det ydre og det indre frihedsproblem hos Sørensen er to sider af samme sag. Det overså fagkritiske humanister efter 68 , når de tilsyneladende gik over åen efter vand $\mathrm{og}$ læste Norman O. Brown og Marcuse for at skaffe sig indsigt $i$ dette.

Kunne de have fået samme indsigt ved at læse Villy Sørensen? Jeg er mere skeptisk end Bonde Jensen på dette punkt, for det forekommer mig, at Sørensen i sin diagnose af frihedsproblemet $i$ 60 ernes velfærdssamfund faktisk i høj grad kom til at skille den ydre og den indre frihed ad.

Det var ikke ham, der under Kunstfonddebatten sagde, at nu var de ydre problemer løst, nu stod kun de psykologiske tilbage. Det var Lembourn. Men Sørensen sagde i de tidlige 60ere, og Bonde 
Jensen citerer ham for det: ' $\mathrm{Nu}$ falder det naturligt at lægge lige så stor vægt på de psykologiske [problemer], eftersom den menneskelige frigørelse er blevet problem i de samfund, hvor menneskene har fået flere friheder og mere fritid.' (s. 184). Og i 'Hverken-eller' havde han talt om, at 'en psykologisk frigørelse må slutte sig til den økonomiske' (s. 199).

Pudsigt nok tolker Bonde Jensen sådanne udtalelser som materialistisk indsigtsfulde. De viser, mener han, at Sørensen som Brecht anser de materielle fornødenheder tilfredsstillelse som en forudsætning for moralen, den indre frihed. Men betænker man, hvilket samfund talen konkret er om, er formuleringerne mystificerende. Mystifikationen består i, at Sørensen totalt udelader af sine betragtninger, at just de samfundsforhold, der omtales som økonomisk frigørelse - dvs. velstandssamfundets fremkomst med dets produktionsomlægninger - $i$ sig selv var årsag til en række nye (fysiske og) psykiske sygdomme: stress, indholdstømning af arbejdsfunktioner og dermed oplevelse af meningsløshed, narcissistiske beskadigelser, osv.

Det var ikke restproblemer, vi nu kunne tage fat på, efter at velstandsstigningen havde givet os tid og kræfter til det. Det var $i$ høj grad problemer, den 'ydre' udvikling havde skabt.

Dette er mere en kritik af Bonde Jensen end af Sørensen, for hvem havde ved 60ernes start mulighed for at se konsekvenserne af en samfundsudvikling,der just var begyndt? Sørensen ser dem selv idag, det viser 'Oprør fra midten'. Og Bonde Jensen ser dem. Men hvilken pietetsfølelse får ham til at digte en indsigt ind i Villy Sørensens 60er-forfatteskab, som notorisk er fraværende? Villy Sørensen begreb ikke dengang forholdet mellem ydre og indre frihed i sin egen samtid materialistisk, og det var der næppe ret mange andre, der gjorde.

Det er min vigtigste indvending mod 'Litterær arkæologi'. Bonde Jensen overspiller sit prisværdige forsøg på at fremdrage materialistiske tendenser i forfatterskabet; Sørensen gøres til materialist også i sammenhænge, hvor han ikke er det. Og dermed løses han alligevel tildels ud af den historiske sammenhæng, som Bonde Jensen ellers har set ham i.

En side af dette er, at Bonde Jensen er for arbødig over for Sørensen som socialpsykolog. Sørensen viser med 'Formynderfortællinger' stor indsigt i den traumatiske psyke, og i sin essayistik har han begrebsliggjort og praktisk anvendt sin socialpsykologiske viden, bl.a. ved hjælp af Broch og Mitscherlich. Men vi ved på 
mange punkter mere om den slags problemstillinger idag, og når Bonde Jensen understreger, at Sørensens psykologi udvikler sig i materialistisk retning frem til 64, burde han også tilføje, at Sørensen gennem de sidste 10 år har været mere interesseret $\mathrm{i}$ instinktpsykologi (Konrad Lorenz, f.eks.) end i socialiseringsteori.

Denne erkendelsesinteresse får praktiske konsekvenser, således i det handlingsforeskrivende manifest 'Oprør fra midten', hvor Sørensen efter min opfattelse forkorter socialpsykologiske problemstillinger ad absurdum, når hans tro på, at mennesket allerede 'er noget' af naturen, føres ind $i$ en hvilken som helst argumentation. Der er for meget Lorenz og for lidt Lorenzer i overvejelser som denne (der tydeligvis har hverken Niels Meyer eller Helveg Petersen som ophavsmand): 'Menneskets forbløffende beredvillighed til lydighed i ekstreme situationer kan ikke forstås som ren og skær fejhed, men må bunde i en primitiv trang til at vide sig styret, et infantilt behov for ledelse.' ('Oprør fra midten', s. 104). Jeg kan komme på flere gode grunde end underkastelsesinstinktet til, at mennesker lader sig manipulere.

Det skal dog tilføjes, at Bonde Jensen flygtigt omtaler mangler ved formynderfortællingernes (de nutids- og fremtidsorienteredes) psykologiske forklaringer. Forklaringen på den massepsykologiske afmagt 'overskrider ikke det primære formynderforholds forklaringsmodel' (s. 189).

Også i andre henseender er der problemer ved at gøre Sørensens kulturradikale indsigter til vore. Klasseopfattelsen hos ham kan ikke kaldes materialistisk, arbejderklassen er temmelig fravarende i hans overvejelser over samfundsudviklingen. Ja, den synes faktisk i højere grad at være ikke-eksisterende end håbløst integreret (som $\mathrm{i}$ Adornos og Marcuses skrifter fra samme tid). Jeg tror, at Sørensens centrale stilling op gennem 60erne bidrog til, at danske intellektuelle så længe så bort fra fundamentale klasseantagonismer (det har naturligvis også andre årsager).

Hvordan forholder det sig i 'Formynderfortællinger'? Her gør Bonde Jensen, med sine aktualiseringsbestræbelser, Sørensen en gevaldig bjørnetjeneste. Han finder nemlig, at den proletariske karaktertype faktisk optræder, omend rudimentært. Tilsyneladende forsigtigt skriver han: 'Piccoloen i Fuglen i jomfruham og de unge sorthårede mænd i I det fremmede er streger til skitser af denne proletariske karaktertype.' (s. 189).

De kan højst være streger til en borgerlig angstprojektion, hvad 
Bonde Jensens egen analyse allerede har vist. Piccoloen er en tyveagtig skade, et ubekymret, afstumpet kneppedyr. De sorthårede mænd er (som de fremtræder for hovedpersonens bevidsthed) nogle typiske sydlandske driverter, drikfældige, med stikkende øjne og tvetydig grimasseren. Man kan selvfølgelig sige, at de besiddelsesløse umyndiggjorte således er 'kommet med'. Men hvorledes? Som bærere af mere privilegeredes driftsprojektioner, som truende randeksistenser.

Det er ikke afgørende i denne forbindelse, om projektionerne er Sørensens egne eller hans personers (men de er sikkert det sidste). Det afgørende er, at proletariatets tilsynekomst i fortællingerne hverken leverer streger eller skitser til en proletarisk karaktertype. Bonde Jensens påpegning af denne karaktertypes tilstedeværelse et led i hans påberåbelse af Sørensens aktualitet som materialist - er en god gerning, som alle bør betakke sig for.

Min konklusion bliver alligevel, at 'Litterær arkæologi' er et spændende - og meget oplagt skrevet - korrektiv til gængse forestillinger på venstrefløjen om Sørensen og kulturradikalismen. Den er nyttig i tre henseender: Den foretager en kvalificeret og meget indgående læsning af et af 60ernes mest indflydelsesrige, men mindst tilgængelige værker. Den peger på forskellige historiske baggrunde for forestillinger, som siden er kritiseret fra materialistisk hold ud fra besynderligt umaterialistiske præmisser. Og endelig leverer den et forsvar for disse forestillingers aktuelle relevans.

Denne relevans er undertiden overbevisende fremargumenteret. Fortællingerne er ikke blot et godt arkæologisk materiale for studiet af kulturradikalismen omkring 60. Deres egen litterære arkæologi rummer masser af impulser for nutidig historieskrivning, fiktiv og faglig - som i øvrigt også 'Seneca'-bogen fra 1976 gør det.

Alligevel er det i forbindelse med aktualitetsværdien, jeg har haft indvendinger. Bonde Jensen har med sit advokatur gjort en storre materialist ud af Sørensen, end han faktisk var - og havde nogen rimelig mulighed for at være - på dette tidspunkt. Og han har renonceret på noget af sin egen indsigtsfuldhed for at stille sig solidarisk med Sørensen på standpunkter, som må siges at være mere arkæologiske end aktuelle.

Jeg vil håbe, at begge bøger - både 'Formynderfortællinger' og 'Litterær arkæologi' - vil blive læst opmærksomt af studerende, der 
ikke selv har nogen erindring om tiden før 68.

Søren Schou 